\title{
Occurrence of Virulence Genes Associated with Human Pathogenic Vibrios Isolated from Two Commercial Dusky Kob (Argyrosmus japonicus) Farms and Kareiga Estuary in the Eastern Cape Province, South Africa
}

\author{
Justine Fri ${ }^{1, *}$, Roland Ndip Ndip ${ }^{1,2}$, Henry Akum Njom ${ }^{1}$ and Anna Maria Clarke ${ }^{1}$ \\ 1 Microbial Pathogenicity and Molecular Epidemiology Research Group (MPMERG), \\ Department of Biochemistry and Microbiology, University of Fort Hare, Alice 5700, South Africa; \\ ndip3@yahoo.com (R.N.N.); hnjom@ufh.ac.za (H.A.N.); aclarke@ufh.ac.za (A.M.C.) \\ 2 Department Microbiology and Parasitology, University of Buea, P.O. Box 63, Buea, Cameroon \\ * Correspondence: frijustine2000@gmail.com; Tel.: +27-(0)8-3984-4664
}

Received: 11 August 2017; Accepted: 21 September 2017; Published: 25 September 2017

\begin{abstract}
Background: Seafood-borne Vibrio infections, often linked to contaminated seafood and water, are of increasing global public health concern. The aim of this study was to evaluate the prevalence of human pathogenic vibrios and their associated virulence genes isolated from fish and water samples from 2 commercial dusky kob farms and Kareiga estuary, South Africa. Methods: A total of 200 samples including dusky kob fish $(n=120)$ and seawater $(n=80)$ were subjected to Vibrio screening on thiosulfate-citrate-bile salts-sucrose agar (TCBS). Presumptive isolates were confirmed and delineated to $V$. cholerae, V. parahaemolyticus, V. vulnificus, and V. fluvialis by PCR. Various pathogenic gene markers were screened: $V$. parahaemolyticus (trh and $t d h$ ), V. vulnificus $(v c g E$ and $v c g C)$ and $V$. fluvialis (stn, vfh, hupO, vfpA). Restriction Fragment Length Polymorphism (RFLP) of the vvhA gene of $V$. vulnificus strains was performed to determine the associated biotypes. Results: Total Vibrio prevalence was $59.4 \%(606 / 1020)$ of which $V$. fluvialis was the most predominant 193 (31.85\%), followed by Vibrio vulnificus $74(12.21 \%)$ and V. parahaemolyticus $33(5.45 \%)$. No V. cholerae strain was detected. One of the $V$. parahaemolyticus strains possessed the trh gene 7 (9.46\%) while most $(91.9 \% ; 68 / 74) \mathrm{V}$. vulnificus isolates were of the E-type genotype. $V$. fluvialis virulence genes detected were $\sin (13.5 \%)$, hupO (10.4\%) and vfpA (1.0\%). 12.16\% (9/74) of V. vulnificus strains exhibited a biotype 3 RFLP pattern. Conclusions: This is the first report of potentially pathogenic vibrios from healthy marine fish in the study area, and therefore a public health concern.
\end{abstract}

Keywords: marine fish; human pathogenic vibrios; virulence; human health

\section{Introduction}

In recent years, there have been concerns about the microbiological safety of fish and other seafood due to increased outbreaks of seafood-borne pathogens. Members of the genus Vibrio are among the bacterial pathogens increasingly implicated in seafood-associated infections [1]. Although not all species of the genus are pathogenic to humans, incidences of human Vibrio-related illnesses over the last few years have been on the rise, particularly in developing countries, with Vibrio cholerae, $V$. vulnificus, $V$. parahaemolyticus and $V$. fluvialis being the most important [2,3]. Only toxigenic strains of $\mathrm{O} 1$ and $\mathrm{O} 139 \mathrm{~V}$. cholerae are associated with cholera illness; however, other strains belonging to non-O1/non-O139 have been associated with sporadic outbreaks of diarrhoea through the ingestion of contaminated seafood [4]. V. parahaemolyticus is one of the leading causes of seafood-associated 
diarrhoeal infection in many countries including the United States, Asian and other developing countries [5-9]. It is one of the frequent causative agents of gastroenteritis, caused by the consumption of raw, undercooked seafood. Although it is best known for causing gastroenteritis, cases of wound infections and septicaemia caused by V. parahaemolyticus have been reported [6,10]. Vibrio vulnificus, on the other hand, is a notorious pathogen in aquaculture and marine environments. It is second to $V$. parahaemolyticus as the most frequently encountered bacterial species that cause infection of food-borne origin and has received attention due to the high mortality rate of infection, making it a significant health risk [11]. Infection with this pathogen is invasive, and it causes either gastroenteritis or necrotizing wound infections, both which may lead to septicaemia [5]. Three V. vulnificus biotypes have been described. Biotype 1 is the most common worldwide, is primarily a human pathogen, and is responsible for numerous clinical cases of the disease [12]. Biotype 2 strains are primarily eel pathogens, which cause eel vibriosis or death and may be opportunistic for humans [13]. Biotype 3 , is the most recently discovered, is known to be geographically restricted to Israel where it caused an outbreak of disease in fish farmers and consumers of Tilipia fish [12,14]. Vibrio fluvialis has been termed an "emerging" pathogen, due to the increased numbers of cholera-like diarrheal outbreaks and sporadic extra-intestinal cases attributed to it [15]. In the last decade, it has been reported in a variety of sources including aquaculture [16], final effluents of waste water treatment plants [17], fish and other seafood [18].

Human pathogenic vibrios produce a wide array of virulence factors which contribute to mild to fatal illnesses [2]. Largely, V. cholerae's ability to cause disease is dependent on the production of two major virulence determinants, cholera toxin (CT) and the toxin-coregulated pilus (TCP). The CT is encoded by the $\operatorname{ctx} A$ and $\operatorname{ctx} B$ genes found on the intergrated prophage $\mathrm{CTX} \varphi$ and it is responsible for the manifestation of diarrhoea with severe water and electrolyte loss [19]. The TCP on the other hand, encoded by $\operatorname{tcp} A$, is required for $V$. cholerae colonisation of the small intestinal epithelium [19]. The expression of these genes is controlled by the toxR regulon, in response to in vivo stimuli [20]. The thermostable direct hemolysin $(t d h)$, in particular, as well as the thermostable direct hemolysin-related gene (trh) are major contributors to the pathogenicity of $V$. parahaemolyticus [8,21], owing to its biological activities, including its cytotoxic and enterotoxic effects [10]. The virulence of $V$. vulnificus is mainly coded for by the virulence-correlated gene $(v c g)$. Differences in virulence degrees have been found in two major genotypes, with the degree of virulence being related to the origin of the strain, with clinical strains displaying higher virulence than environmental isolates [22]. V. fluvialis, on the other hand is known to produce several potent toxins including the heat stable enterotoxin $(s t n)$, although their roles in pathogenesis are not well established [23]. However, as is the case with $V$. cholerae, the toxR plays an important role in the bile resistance of $V$. fluvialis, an initial phase in the establishment of the disease. Other virulence factors include the heme utilization protein gene (hupO), extracellular haemolysin gene (vfh), and the $V$. fluvialis protease gene (vfp) [24].

A few reports on pathogenic vibrios in South Africa have been made, mostly from final effluents of waste water treatment plants [25-27]. However, recent epidemiological data is lacking. There is also little attention being paid to the occurrence of these pathogens in seafood or fish of commercial interest, which could be major source of seafood infection. We therefore investigated the occurrence of human pathogenic vibrios in dusky kob fish as well as water samples from two commercial farms and the Kareiga Estuary and investigated the presence of virulent associated genes that may aid in pathogenicity, which presents a guide to the risk they may pose to the community.

\section{Materials and Methods}

\subsection{Sampling}

An ethical clearance for the study was obtained from the University of Fort Hare Research Ethics Committee (UREC) (CLA011SFRI01). Water and fish samples were harvested from two aquaculture dusky kob farms: Farm 1, with coordinates $13.0670^{\circ}$ N, $59.5712^{\circ}$ W, and Farm 2, with coordinates 
$32.9638^{\circ} \mathrm{S}, 27.8789^{\circ} \mathrm{E}$, in the Eastern Cape Province and from the Kariega Estuary $\left(33^{\circ} 41^{\prime} \mathrm{S}, 24^{\circ} 44^{\prime} \mathrm{E}\right)$. Samples from the wild were purchased directly from fishermen as they came ashore or captured by fishing experts from SAIAB (South African Association for Aquatic Biodiversity). Upon capture, all fish were inspected for signs of any disease or abnormality, of which none were evident. Therefore, only healthy juveniles of consumption size (body mass of $\geq 0.6 \mathrm{Kg}$ ), approximately $\geq 7$ months old were included in the study. Sampling was spread between November 2014 and October 2015, spanning the four seasons of the year. A total of 120 dusky kob fish (100 from fish farms and 20 from the wild) and 80 water samples were included in the study. The fish were ice killed and placed immediately in sterile zip lock bags post-harvest. Water was aseptically collected in sterile $2 \mathrm{~L}$ bottles from fish tanks at harvest as well as from the Kariega estuary during each sampling. Fish and water samples were transported in cool chain to the laboratory and processed within $4 \mathrm{~h}$ of collection.

\subsection{Bacteriological Analyses}

The outer surfaces of the fish were rinsed with sterile distilled water prior to bacteriological analysis. The skin, gill and gut were aseptically excised with a scalpel and scissors and homogenised. A 1:10 broth dilution enrichment of homogenate into alkaline peptone water (Oxoid, Basingstoke, UK), $\mathrm{pH}$ 8.6, was carried out and this was incubated at $37^{\circ} \mathrm{C}$ for $4-6 \mathrm{~h}$, and further sub-cultured on thiosulfate-citrate-bile salts-sucrose (TCBS) agar (Oxoid, Basingstoke, UK). To enhance detection of Vibrio species from water samples, analysis was done according to American Public Health Association (APHA) [28], where $100 \mathrm{~mL}$ each of water samples were filtered through a $0.45-\mu \mathrm{m}$ membrane, with the membrane inoculated on TCBS (Oxoid, Basingstoke, UK) as well as pre-enrichment of water samples in APW prior to culture on TCBS. Following $24-48 \mathrm{~h}$ incubation, $2-5$ distinctive presumptive Vibrio colonies per TCBS plate were inoculated in brain heart infusion (BHI) agar (Oxoid, Basingstoke, UK) for purity and incubated at $37^{\circ} \mathrm{C}$ for $24 \mathrm{~h}$. Preliminary tests on presumptive isolates included gram staining, oxidase (using of oxidase test strips (MB0266A, MICROBACT ${ }^{\mathrm{TM}}$ Oxoid, Basingstoke, UK) and catalase tests.

\subsection{Molecular Confirmation of Vibrio Species}

Presumptive Vibrio isolates were subjected to a polymerase chain reaction (PCR) assay for molecular identification. DNA was isolated by the boiling method where pellets from $18-24 \mathrm{~h}$ broth cultures were suspended in $200 \mu \mathrm{L}$ of sterile distilled water, and cells lysed by boiling $\left(100{ }^{\circ} \mathrm{C}\right.$ for $15 \mathrm{~min}$ ) in a digital Accu dri-block (Lasec, Capetown, SA). Cell debris was removed by centrifugation at $13,000 \times \mathrm{g}$ for $5 \mathrm{~min}$ and the supernatants were used directly as templates in PCR reactions or stored in $50 \mu \mathrm{L}$ aliquots at $-20{ }^{\circ} \mathrm{C}$ until use. Primers targeting the $16 \mathrm{~S}$ rRNA gene variable region that spans between $700 \mathrm{bp}$ and $1325 \mathrm{bp}$ were used to confirm whether isolates belonged to the genus Vibrio [29]. Confirmed isolates were further delineated to four human pathogenic species: V. cholerae, $V$. paraheaemolyticus, $V$. vulnificus and $V$. fluvialis. Vibrio cholerae, $V$. paraheaemolyticus and V. vulnificus were detected by multiplex PCR using species-specific primers as reported earlier [30], while single PCRs were performed to detect $V$. fluvialis [23]. Vibrio cholerae was also detected by targeting the ompW gene [31]. The various primer sets used for PCR confirmation and species differentiation are shown on Table 1. V. vulnifius ATCC 27562, V. parahaemolyticus ATCC 17802 and V. fluvialis ATCC 33809, as well as extracted DNA from a confirmed O139 V. cholerae strain (obtained from the Microbiology laboratory of the Natural Resources and the Environment (NRE), Council for Scientific Research (CSIR)) were used as positive controls. 
Table 1. Primer sequences and expected amplicon size of PCR amplified gene targets for Vibrio species.

\begin{tabular}{|c|c|c|c|c|c|}
\hline Target Species & $\begin{array}{l}\text { Target } \\
\text { Gene }\end{array}$ & Primer Sequence $\left(5^{\prime}-3^{\prime}\right)$ & $\begin{array}{l}\text { Amplicon } \\
\text { Size (bp) }\end{array}$ & Cycling Conditions & References \\
\hline Vibrio & $\begin{array}{c}16 \mathrm{~S} \\
r R N A\end{array}$ & $\begin{array}{l}\text { CGGTGAAATGCGTAGAGAT } \\
\text { TTACTAGCGATTCCGAGTTC }\end{array}$ & 663 & $\begin{array}{l}\text { Initial denaturation at } 94^{\circ} \mathrm{C} \text { for } 5 \mathrm{~min}, \\
\text { followed by } 35 \text { cycles at } 94^{\circ} \mathrm{C} \text { for } 30 \mathrm{~s}, 52^{\circ} \mathrm{C} \\
\text { for } 30 \mathrm{~s} \text { and } 72^{\circ} \mathrm{C} \text { for } 60 \mathrm{~s} \text {. Final extension } \\
\text { was at } 72^{\circ} \mathrm{C} \text { for } 10 \mathrm{~min} \text {. }\end{array}$ & [29] \\
\hline V. parahaemolyticus & toxR & $\begin{array}{l}\text { TGTACTGTTGAACGCCTAA } \\
\text { CACGTTCTCATACGAGTG }\end{array}$ & 503 & \multirow{3}{*}{$\begin{array}{l}\text { Initial denaturation at } 94^{\circ} \mathrm{C} \text { for } 5 \mathrm{~min}, \\
\text { followed by } 35 \text { cycles of } 94{ }^{\circ} \mathrm{C} \text { for } 30 \mathrm{~s}, 55^{\circ} \mathrm{C} \\
\text { for } 30 \mathrm{~s} \text { and } 72{ }^{\circ} \mathrm{C} \text { for } 30 \mathrm{~s} \text {. A final extension } \\
\text { step at } 72{ }^{\circ} \mathrm{C} \text { for } 10 \mathrm{~min} \text {. }\end{array}$} & \multirow{3}{*}{ [30] } \\
\hline V. vulnificus & vohA & $\begin{array}{l}\text { ACTCAACTATCGTGCACG } \\
\text { ACACTGTTCGACTGTGAG }\end{array}$ & 366 & & \\
\hline \multirow[b]{2}{*}{ V. cholerae } & toxR & $\begin{array}{l}\text { GAAGCTGCTCATGACATC } \\
\text { AAGATCAGGGTGGTTATTC }\end{array}$ & 275 & & \\
\hline & $\mathrm{OmpW}$ & $\begin{array}{l}\text { CACCAAGAAGGTGACTTTATTGTG } \\
\text { GGTTTGTCGAATTAGCTTCACC }\end{array}$ & 304 & $\begin{array}{l}\text { Initial denaturation at } 94^{\circ} \mathrm{C} \text { for } 10 \mathrm{~min} \text {, } \\
\text { followed by } 30 \text { cycles at } 94^{\circ} \mathrm{C} \text { for } 60 \mathrm{~s}, 59^{\circ} \mathrm{C} \\
\text { for } 60 \mathrm{~s} \text { and } 72{ }^{\circ} \mathrm{C} \text { for } 2 \mathrm{~min} \text {. Final elongation } \\
\text { step at } 722^{\circ} \mathrm{C} \text { for } 10 \mathrm{~min} \text {. }\end{array}$ & [31] \\
\hline V. fluvialis & toxR & $\begin{array}{l}\text { GGATACGGCACTTGAGTAAGACTC } \\
\text { GACCAGGGCTTTGAGGTGGACGAC }\end{array}$ & 217 & $\begin{array}{l}\text { Initial denaturation step at } 94^{\circ} \mathrm{C} \text { for } 5 \mathrm{~min} \text {, } \\
\text { followed by } 30 \text { cycles at } 94{ }^{\circ} \mathrm{C} \text { for } 30 \mathrm{~s}, 57^{\circ} \mathrm{C} \\
\text { for } 60 \mathrm{~s} \text { and } 72{ }^{\circ} \mathrm{C} \text { for } 90 \mathrm{~s} \text {. A final extension } \\
\text { step at } 72^{\circ} \mathrm{C} \text { for } 7 \mathrm{~min} \text {. }\end{array}$ & [23] \\
\hline
\end{tabular}

\subsection{Detection of Virulence Genes}

PCR confirmed $V$. parahaemolyticus isolates were screened for the presence of $t$ dh and trh virulence genes using previously reported primers [32], while $V$. vulnificus virulence genes (vcgE and $v c g C)$ were detected as previously described [33]. Four gene-specific primer sets (Table 2) were used in a touch-down multiplex PCR amplification of $V$. fluvialis virulence genes, heat stable enterotoxin (stn), heme utilization protein gene (hupO), extracellular haemolysin gene ( $v f h$ ) and $V$. fluvialis protease gene (vfp) [24]. Table 2 indicates the target genes and primer sets used for detection of Vibrio virulence genes. All amplifications were performed in $25 \mu \mathrm{L}$ reactions, each consisting of $12.5 \mu \mathrm{L}$ of $2 \times$ master mix (Thermo scientific, Johannesburg, South Africa), $0.5 \mu \mathrm{L}$ of each oligonucleotide (Inqaba Biotec, Pretoria, South Africa), and an appropriate volume of nuclease free water (Thermo scientific, Waltham, MA, USA). PCR products were separated by electrophoresis in 1-2\% agarose gels containing $5 \mu \mathrm{g} / \mathrm{mL}$ ethidium bromide (Sigma-Aldrich, St. Louis, MO, USA) run at $100 \mathrm{~V}$ for $45 \mathrm{~min}$ and visualised under a UV transilluminator (Alliance 4.7 XD-79, Uvitec, Cambridge, UK).

Table 2. Primer sets used in the detection of Vibrio virulence genes.

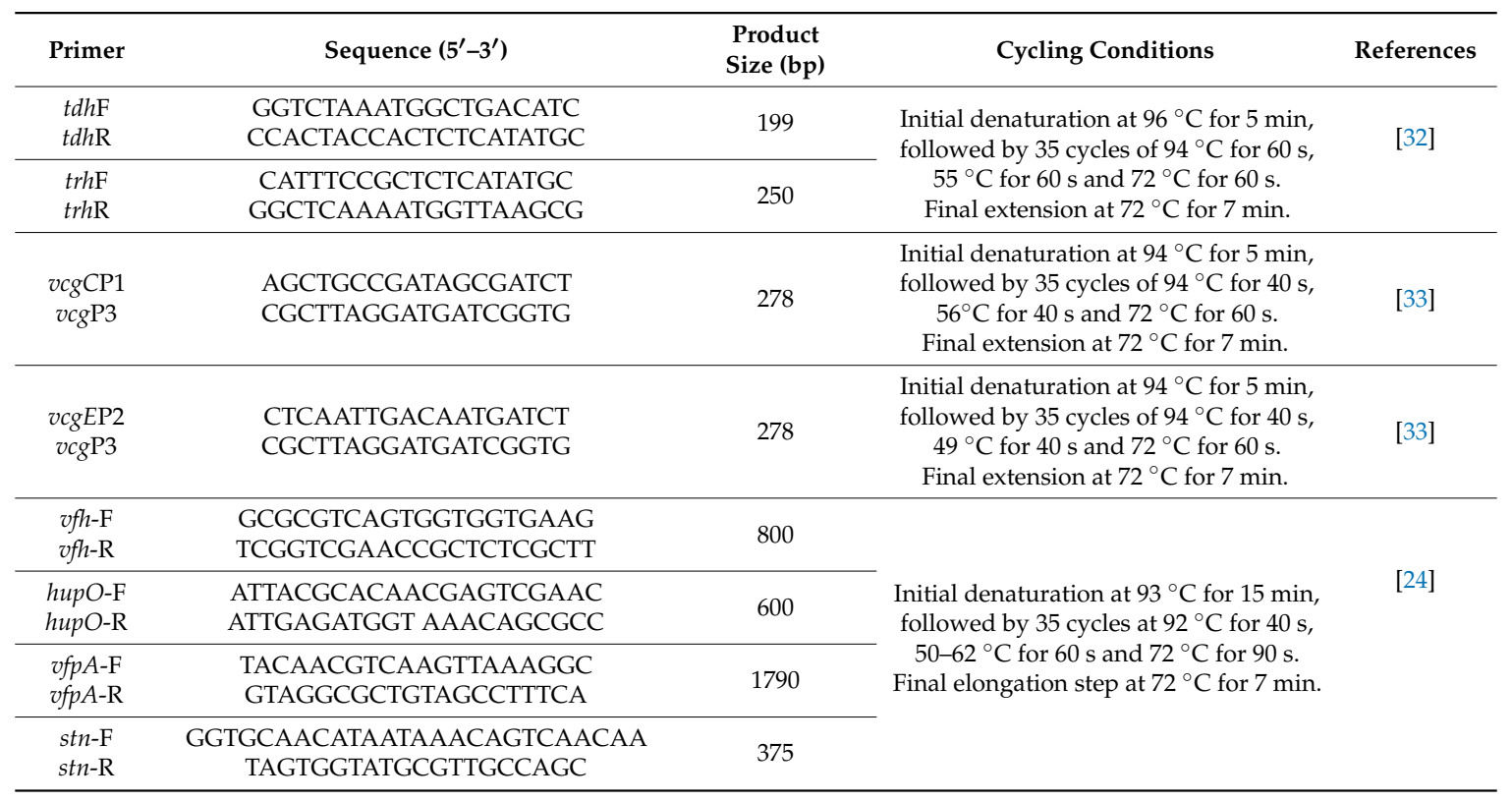




\subsection{Biotyping of V. Vulnificus}

The restriction fragments of the $v v h \mathrm{~A}$ gene obtained using KpnI or PstI can be used to differentiate biotype 3 from biotypes 1 and 2 [34]. The vvhA nucleotide sequence of biotype 3 strains contain restriction sites for these enzymes while those of biotypes 1 and 2 do not. Biotyping of the confirmed V. vulnificus strains was therefore carried out as earlier reported [34]; the $V$. vulnificus cytotoxin-hemolysin gene $(v v h A)$ was amplified using the primer pair Fw $5^{\prime}$ CAGCTCCAGCCGTTAACCGAACCACCCGC- $3^{\prime}$ and Rv $5^{\prime}$-TTCCAACTTCAAACCGAACTATGAC- $3^{\prime}$. Amplicons were resolved on $1.5 \%$ agarose gel followed by restriction fragment length polymorphism (RFLP). The two restriction enzymes, (KpnI and $P s t \mathrm{I}$ ), were used for restriction digest following the manufacturer's instructions (New England Biolabs, Ipswich, MA, USA). The restricted digests were separated by electrophoresis in $2 \%$ agarose gels and visualised in a UV transilluminator (Alliance 4.7 XD-79, Uvitec, Cambridge, UK).

\section{Results}

\subsection{Prevalence of Vibrio Species}

A total of 1020 presumptive isolates were obtained by culture, of which $606(59.4 \%)$ were positive by PCR as belonging to the genus Vibrio (Figure 1). Vibrio fluvialis was the most predominant, $193(31.85 \%)$, followed by V. vulnificus, $74(12.21 \%)$ and V. parahaemolyticus 33 (5.45\%) (Table 3, Figures 2 and 3). No $V$. cholerae was detected. The rest of the isolates, 306 (50.5\%) were assumed to belong to other species of the genus not considered in this study.

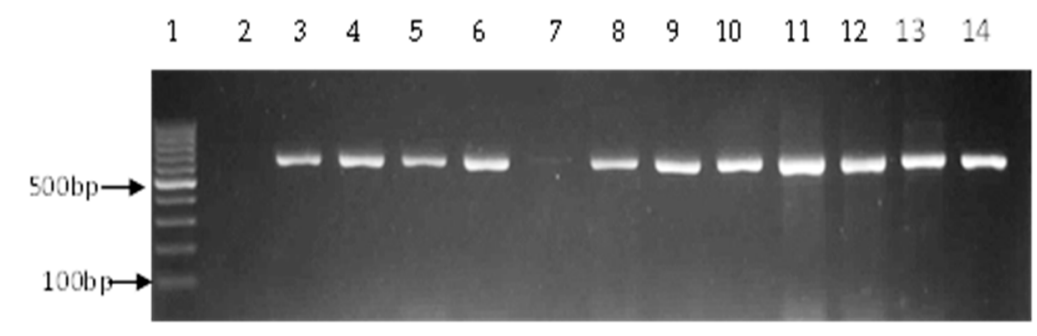

Figure 1. Representative gel showing the $663 \mathrm{bp} 16 \mathrm{~S}$ rRNA PCR amplified gene for confirmation of Vibrio isolates. Lane 1: molecular weight marker (100 bp), lane 2: negative control, lane 3: positive control (ATCC 17802), lanes 4-6 and 8-14: positive isolates, lane 7: negative isolate.

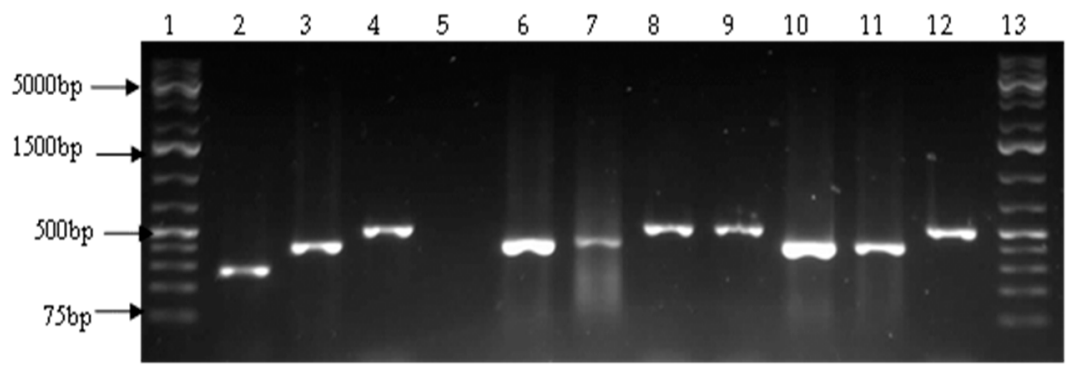

Figure 2. A representative agarose gel showing the $275 \mathrm{bp}, 366 \mathrm{bp}$ and $503 \mathrm{bp}$ PCR products of $V$. cholerae toxR, V. vulnificus $v v h A$ and $V$. parahaemolyticus toxR genes respectively. Lanes 1 and 13: molecular weight markers (1 kb plus), Lane 2: V. cholerae positive control (O139 positive DNA from CSIR, SA), lane 3: V. vulnificus positive control (ATCC 27562), lane 4: V. parahaemolyticus positive control (ATCC 17802), Lane 5: negative control, Lanes 6, 7, 10 and 11: $V$. vulnificus positive isolates, and lanes 8, 9 and 12: V. parahaemolyticus positive isolates. 


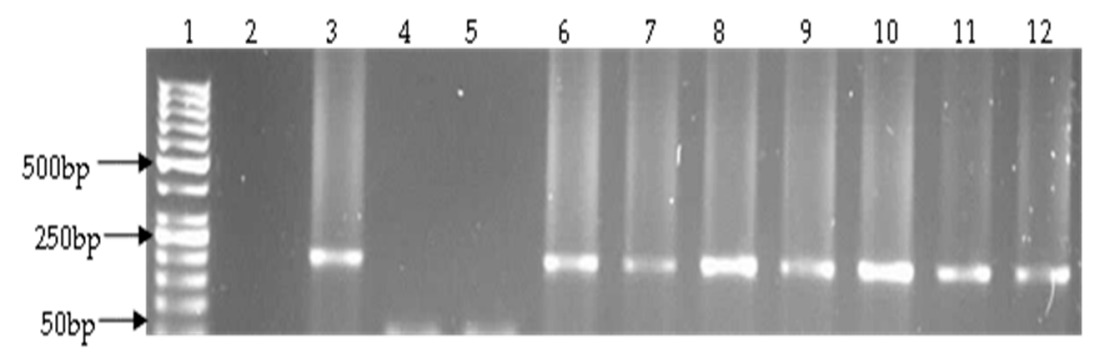

Figure 3. Representative gel showing the $217 \mathrm{bp}$ PCR amplified $V$. fluvialis toxR gene. Lane 1: molecular weight marker (50 bp), lane 2: negative control, lane 3: positive control (ATCC 33809), lanes 4 and 5: negative isolates, lanes 6-12: positive isolates.

Table 3. Distribution and frequency of occurrence of PCR confirmed Vibrio strains isolated from water and fish samples.

\begin{tabular}{cccccc}
\hline \multirow{2}{*}{ Sampling Site } & $\begin{array}{c}\text { Source }(\boldsymbol{n}=\text { No. of Vibrio } \\
\text { Positives by PCR) }\end{array}$ & V.fluvialis & V. parahaemolyticus & V. vulnificus & \multirow{2}{*}{ Total } \\
\cline { 3 - 5 } & Water $(n=39)$ & $3(7.69 \%)$ & $4(10.26 \%)$ & $0(0.00 \%)$ & $7(17.95 \%)$ \\
Kariega & Fish $(n=57)$ & $7(12.28 \%)$ & $5(8.77 \%)$ & $1(1.75 \%)$ & $13(22.81 \%)$ \\
Estuary & Water $(n=73)$ & $54(73.97 \%)$ & $4(5.48 \%)$ & $2(2.74 \%)$ & $60(82.19 \%)$ \\
\multirow{2}{*}{ Farm 1} & Fish $(n=290)$ & $109(37.59 \%)$ & $14(11.93 \%)$ & $61(55.96 \%)$ & $184(63.45 \%)$ \\
& Water $(n=45)$ & $5(11.11 \%)$ & $3(6.67 \%)$ & $5(11.11 \%)$ & $13(28.89 \%)$ \\
\multirow{2}{*}{ Farm 2} & Fish $(n=102)$ & $15(14.71 \%)$ & $3(2.94 \%)$ & $5(4.91 \%)$ & $23(22.55 \%)$ \\
\hline \multirow{2}{*}{ Total } & 606 & $193(31.85 \%)$ & $33(5.45 \%)$ & $74(12.21 \%)$ & $300(49.50 \%)$ \\
\hline
\end{tabular}

\subsection{Prevalence of Vibrio Virulence Genes}

Most $(97.0 \%$; 32/33) V. parahemolyticus species were negative for $t d h$ gene, while one wild fish isolate was positive for $\operatorname{trh}(3.0 \% ; 1 / 33)$. Genetic variations in the virulence-correlated gene $(v c g)$ serve as a primary feature to distinguish clinical (C-) genotypes from environmental (E-) genotypes. Of the 74 confirmed $V$. vulnificus isolates, $6(8.1 \%)$ had the $v c g C$, while 68 possessed $v c g E(91.9 \%)$. V. fluvialis was screened for the presence of four virulence genes, vfh, hupO, stn, and vfp A. A total of 35 isolates possessed one to three of these genes, with stn being the most prevalent $13.5 \%(26 / 193)$, followed by hupO, 10.4\% (20/193) and vfh 6.2\% (12/193) (Table 4, Figure 4). None of the isolates possessed the vfpA virulence gene.

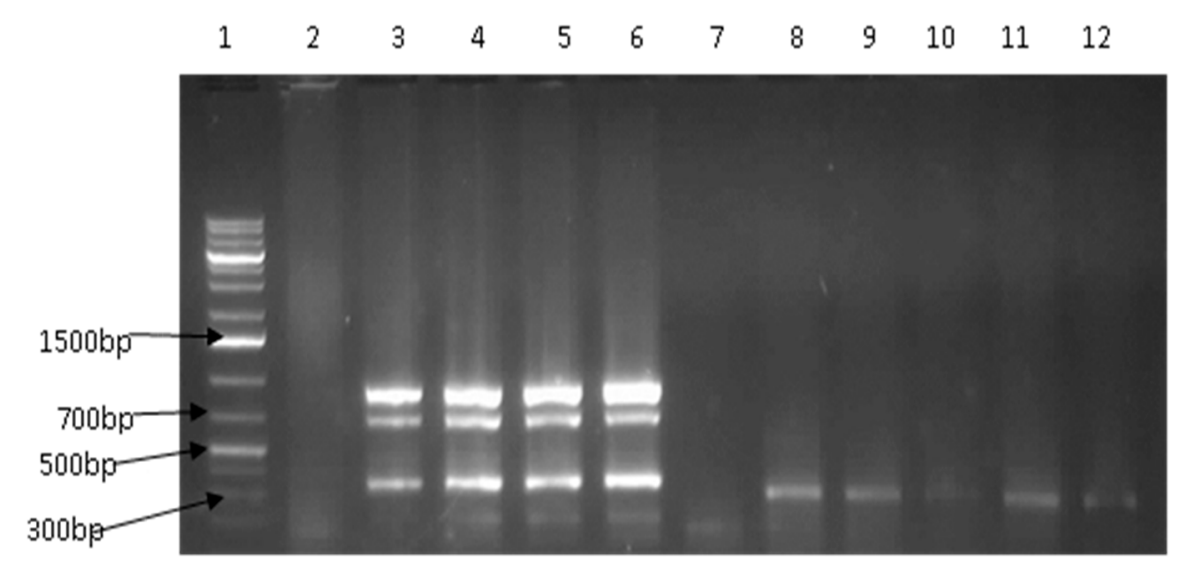

Figure 4. Representative gel of multiplex PCR detected $V$. fluvialis virulence genes. Lane 1: molecular weight marker (1 kb plus), lane 2: negative control, lane 3: positive control, lanes 4-6, 8, 9, 11 and 12: positive for $\operatorname{stn}(375 \mathrm{bp}$ ), lanes 4-6: positive for $v f h$ ( $800 \mathrm{bp}$ ), lanes 4-6: positive for hupO and lanes 7 and 10: negative isolates. 
Table 4. Summary of V. fluvialis virulence genes detected from different sampling sites.

\begin{tabular}{ccccc}
\hline \multirow{2}{*}{ Site } & \multicolumn{3}{c}{ V. fluvialis Virulence Genes } \\
\cline { 2 - 5 } & $\boldsymbol{v} f \boldsymbol{c h}$ & hupO & stn & $\boldsymbol{v f p \mathbf { A }}$ \\
\hline Farm 1 $(n=10)$ & $2(20 \%)$ & $2(20 \%)$ & $2(20 \%)$ & $0(0 \%)$ \\
Farm 2 $(n=163)$ & $10(6.1 \%)$ & $18(11 \%)$ & $21(12.9 \%)$ & $0(0 \%)$ \\
Kareiga Estuary $(n=20)$ & $0(\%)$ & $0(0 \%)$ & $3(15 \%)$ & $0(0 \%)$ \\
Total $(n=193)$ & $12(6.2 \%)$ & $20(10.4 \%)$ & $26(13.5 \%)$ & $0(0 \%)$ \\
\hline
\end{tabular}

Of the $35 \mathrm{~V}$. fluvialis strains that tested positive for virulence genes, three strains were vfh-hupO-stn positive, eight strains were vfh-hupO positive, eight were hupO-stn positive and one strain was vfh-stn positive. The rest were either positive for $\operatorname{stn}(1 / 35)$ or hupO (14/35) only (Table 5).

Table 5. Distribution of virulence genes in $V$. fluvialis strains.

\begin{tabular}{|c|c|c|c|}
\hline \multirow{2}{*}{ Isolate Code } & \multicolumn{3}{|c|}{ V. fluvialis Virulence Genes } \\
\hline & $v f h$ & hupO & stn \\
\hline 11 & & & + \\
\hline 30 & + & + & \\
\hline 36 & + & + & + \\
\hline 57 & & & + \\
\hline 58 & & + & + \\
\hline 72 & & & + \\
\hline $206 a$ & & + & + \\
\hline $207 d$ & & & + \\
\hline $225 b$ & & + & + \\
\hline $231 \mathrm{a}$ & & + & + \\
\hline $241 \mathrm{a}$ & + & + & \\
\hline 241d & + & + & \\
\hline $241 \mathrm{~g}$ & + & + & \\
\hline $241 \mathrm{j}$ & + & + & \\
\hline $252 \mathrm{~g}$ & & + & \\
\hline $253 a$ & & + & + \\
\hline $253 b$ & & + & + \\
\hline $253 c$ & & + & + \\
\hline $253 d$ & & + & + \\
\hline $262 d$ & & & + \\
\hline $271 \mathrm{a}$ & + & + & + \\
\hline $271 b$ & + & + & + \\
\hline $276 b$ & + & + & \\
\hline $276 f$ & + & + & \\
\hline $277 d$ & & & + \\
\hline $278 a$ & + & + & \\
\hline $278 c$ & & & + \\
\hline 289 & + & & + \\
\hline $308 \mathrm{~b}$ & & & + \\
\hline $308 \mathrm{f}$ & & & + \\
\hline $309 a$ & & & + \\
\hline $330 \mathrm{~h}$ & & & + \\
\hline $369 \mathrm{~b}$ & & & + \\
\hline $375 a$ & & & + \\
\hline $379 a$ & & & + \\
\hline Total $(n=35)$ & 12 & 20 & 26 \\
\hline
\end{tabular}

For all $V$. vulnificus strains, the vvhA restriction fragment(s) obtained when digested with KpnI were similar to those obtained when digested with PstI. Restriction sites for both enzymes were present in nine $(12.16 \%)$ of the nucleotide sequences of the $v v h$ A gene revealing biotype 3 with no restriction sites for the majority $(87.84 \%, 65 / 74)$, indicating biotypes 1 and 2 (Figure 5). 


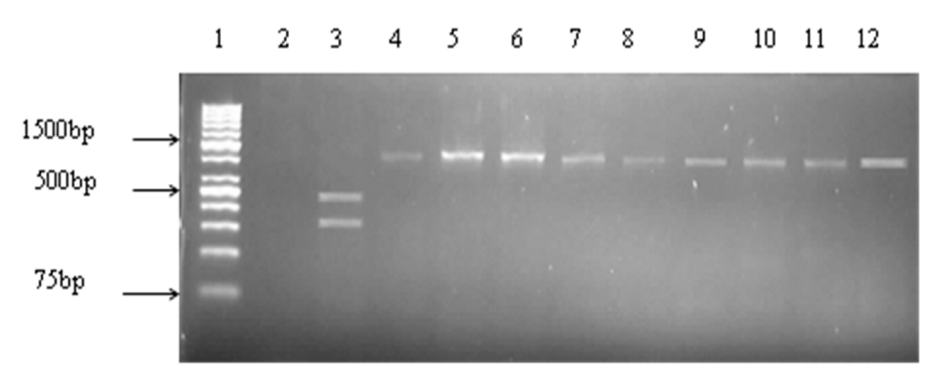

Figure 5. Representative gel of PCR RFLP of Vibrio vulnificus vvhA gene. Lane 1: molecular weight marker (1 kb plus), lane 2: negative control, lane 3: V. vulnificus biotype 3, lanes $4-12, V$. vulnificus biotypes 1 and 2 .

\section{Discussion}

Marine filter feeders are highly susceptible to surface or tissue contamination of marine origin, which may include potential human pathogens. Other marine foods are not exempt from bacterial contamination either. Members of the genus Vibrio are ubiquitous in marine and estuarine waters and therefore the high total prevalence $(59.4 \%)$ recorded in our study was not surprising. What concerned us was the presence of virulence traits among potentially pathogenic vibrios.

Three (V. parahaemolyticus, V. fluvialis, and V. vulnificus) of the four human pathogens considered in this study were detected from the fish and water samples, with some strains harboring one or more virulence determinants. This is similar to an earlier study [35] reporting a number of Vibrio species which are indigenous aquatic bacteria that contaminate fish, including $V$. cholerae, V. parahaemolyticus, and $V$. vulnificus, mostly present in warm $\left(>15^{\circ} \mathrm{C}\right)$ saline waters, and are implicated in many food-borne illnesses. The most frequently isolated non-cholera-causing human pathogenic Vibrio species was $V$. fluvialis, $31.85 \%$ (193/606). This result is similar to others previously reported where V'fluvialis was the most frequently occurring species isolated from fish ponds [36], as well as in a variety of seafood [37]. The high frequency of occurrence of this pathogen in marine reservoirs could point towards why an increasing number of cases in the last decade have been reported terming it "emerging". First reported in 1975 in a patient with diarrhoea in Bahrain [38], V. fluvialis has since become distributed worldwide, and is associated with numerous reports of food poisoning [39,40], as well as gastroenteritis with diarrheal illness connected with the consumption of raw or improperly cooked seafood [41,42]. We also detected V. vulnificus (12.21\%) and V. parahaemolyticus (5.45\%) although at lower frequencies than those recorded in waste water treatment facilities [25-27]. The presence of this pathogen in marine fish and aquaculture could be a source of infection to humans, especially to the immunocompromised. Earlier reports in Israel in 1996 and 1997 [12], implicated V. vulnificus in an outbreak of invasive infection in handlers of whole fresh fish purchased from fish ponds. V. vulnificus was also the source of necrotizing fasciitis that led to the amputation of the lower limb of a 17 year old boy after minor trauma during exposure to a contaminated fish tank [43]. Although cases of V. vulnificus infection may be generally low, it has received attention due to high case fatalities related to consumption of contaminated seafood $[44,45]$.

Bacterial pathogenicity depends on the production of virulence factors, with virulence genes acting as major orchestrators. The dominant virulence factors of $V$. parahaemolyticus with regard to its pathogenicity are $t d h$ and $t r h$ [10]. All $V$. parahemolyticus strains detected in this study were negative for the $t d h$ gene, while $t r h$ was detected in one isolate $(1.4 \%(1 / 33)$. These results are, however, not surprising, as previous reports have indicated the presence of these virulent signatures in only low numbers (1-7\%) in environmental samples [46]. Similarly, Vibrio isolates recovered from West Sumatran rivers and shrimp farms in Sri Lanka were void of these virulence genes [47,48]. A low prevalence $(0 \% t d h$ and $4.2 \% t r h)$ was also recorded from 96 seafood and water samples in Turkey [8]. Although clinical cases of $V$. parahaemolyticus are associated with increased detection of these genes, the continuous report of pathogenic $V$. parahaemolyticus in the last few years and the fact that it is 
the most commonly encountered Vibrio species implicated in seafood infection is an indication that other virulence factors may exist [49-51]. Mahoney et al. [52] reported environmental isolates of $V$. parahaemolyticus lacking the $t d h$ and trh but producing putative virulence factors such as extracellular proteases, biofilm and siderophores. Recently, Raghunath reported finding environmental isolates of $V$. parahaemolyticus lacking the $t d h$ and trh genes but highly cytotoxic to human gastrointestinal cells [53]. Some Vibrio fluvialis strains in this study were found to possess three of the four targeted virulent genes, $\operatorname{stn} 13.5 \%$, hupO $10.4 \%$ and vfh $6.2 \%$. Although prevalence of these genes may be low, it should not be ignored as there are increased reports of this pathogen in the last decade [36,37,40]. Moreover, some of these virulent genes may be transferred to similar or other bacterial species via horizontal gene transfer or mobile genetic elements, leading to virulent human infections. The exotoxin-hemolysin vohA virulence protein produced by $V$. vulnificus facilitates the release of iron from haemoglobin. It also contributes to the bacteria's virulence by producing cytotoxic effects [54]. The virulence correlated gene $v c g$, however, has been one of the major virulence factors of $V$. vulnificus and can be used to distinguish potentially virulent from avirulent strains. The $v c g C$ gene is linked mainly with clinical isolates while the $v c g E$ is linked mostly with environmental isolates [55]. In this study, over $90 \%$ of $V$. vulnificus isolates were of the $v c g E$ genotype, an indication of less virulent strains. This result is similar to that of a study recording a significantly higher percent of the E-genotype of $V$. vulnificus isolates recovered from oysters [56]. Although such a result is expected from environmental samples, it is, however, contrary to a report where nearly an equal percent of $v c g E(47 \%)$ and $v c g C(53 \%)$ were detected from oyster isolates [57] and water areas surrounding oyster harvest [56]. Continuous monitoring of seafood and fish products remains a necessity as infection with $V$. vulnificus, although rare, is usually fatal, particularly in immunocompromised persons.

Restriction digest of $V$. vulnificus vohA gene revealed that most of the isolates belonged to biotypes 1 and 2, while a small percentage (12.16\%), belonged to the biotype 3. Biotype 1 is primarily a human pathogen, and the leading cause of seafood-related deaths due to primary septicaemia [54], while biotype 2 mainly causes eel vibriosis [13]. However, Amaro and Biosca [58], reported a clinical $V$. vulnificus strain isolated from a human wound which belonged to biotype 2 , suggesting that biotype 2 pathogenic for eels are also opportunistic for humans. In addition, some biotype 2 strains isolated from human samples could not be definitively linked to eel exposure or manipulation despite earlier reports to the contrary [13]. Seawater and fish species other than eels have been suggested, therefore to be putative reservoirs of biotype 2 [59]. Results from our study indicate that dusky kob and its surrounding waters are likely to be reservoirs for $V$. vulnificus, which could either cause infection or be opportunistic for humans particularly in persons with underlying disease. The first reported case of $V$. vulnificus biotype 3 determined to be the cause of severe soft tissue infections, and associated with exposure to contaminated fish, (especially tilapia or common carp), was described in 1996-1997 [34]. This biotype is thought to be geographically restricted to Israel. Our study is the first report of V. vulnificus biotype 3 isolated from a marine source in South Africa.

\section{Conclusions}

To the best of our knowledge, our findings represent the first report on the prevalence of human pathogenic Vibrio species with some virulent signatures isolated from healthy marine fish in South Africa. Although no Vibrio cholerae was detected, the occurrence of other human pathogenic vibrios, including $V$. parahaemolyticus, $V$. fluvialis and $V$. vulnificus, (all of which can cause sporadic and epidemic gastroenteritis as well as other serious diseases), is of public concern. Detection of $V$. vulnificus biotype 3 indicates its circulation in the region. Even though transmission of fish pathogens to humans may be relatively low, it is a health risk that needs to be considered by fish farmers, fishermen and others who handle or consume fish products, particularly in conjunction with the increased rate of seafood-associated Vibrio infections. Consumption of properly cooked fish is recommended, while frequent epidemiological studies could be carried out to better understand the associated health risk and implement control strategies for reduction of possible human infections. 
Acknowledgments: The authors are grateful to the South African Institute for Aquatic Biodiversity (SAIAB) and NRF for funding this study. They are also grateful to the directors of the fish farms for provision of samples for the study.

Author Contributions: Justine Fri designed the study, carried out sample collection, laboratory and data analysis, and drafting of manuscript. Henry Akum Njom contributed expert judgments in the laboratory analysis, data interpretation and proof reading of manuscript. Anna Maria Clarke participated in study design, organization of sampling and supervised the experiments. Roland Ndip Ndip participated in study design, and added expert knowledge to the technicalities of the study.

Conflicts of Interest: The authors declare no conflict of interest.

\section{References}

1. Iwamoto, M.; Ayers, T.; Mahon, B.E.; Swerdlow, D.L. Epidemiology of seafood-associated infections in the United States. Clin. Microbiol. Rev. 2010, 23, 399-411. [CrossRef] [PubMed]

2. Eyisi, O.A.; Nwodo, U.U.; Iroegbu, C.U. Distribution of Vibrio species in shellfish and water samples collected from the atlantic coastline of south-east Nigeria. J. Health Popul. Nutr. 2013, 31, 314. [PubMed]

3. Machado, A.; Bordalo, A.A. Detection and Quantification of Vibrio cholerae, Vibrio parahaemolyticus, and Vibrio vulnificus in Coastal Waters of Guinea-Bissau (West Africa). EcoHealth 2016, 13, 339-349. [CrossRef] [PubMed]

4. Dutta, D.; Chowdhury, G.; Pazhani, G.P.; Guin, S.; Dutta, S.; Ghosh, S.; Rajendran, K.; Nandy, R.K.; Mukhopadhyay, A.K.; Bhattacharya, M.K.; et al. Vibrio cholerae non-O1, non-O139 serogroups and cholera-like diarrhea, Kolkata, India. Emerg. Infect. Dis. 2013, 19, 464-467. [CrossRef] [PubMed]

5. Newton, A.; Kendall, M.; Vugia, D.J.; Henao, O.L.; Mahon, B.E. Increasing rates of vibriosis in the United States, 1996-2010: Review of surveillance data from 2 systems. Clin. Infect. Dis. 2012, 54 (Suppl. S5), S391-S395. [CrossRef] [PubMed]

6. Daniels, N.A.; MacKinnon, L.; Bishop, R.; Altekruse, S.; Ray, B.; Hammond, R.M.; Thompson, S.; Wilson, S.; Bean, N.H.; Griffin, P.M.; et al. Vibrio parahaemolyticus infections in the United States, 1973-1998. J. Infect. Dis. 2000, 181, 1661-1666. [CrossRef] [PubMed]

7. Su, H.P.; Chiu, S.I.; Tsai, J.L.; Lee, C.L.; Pan, T.M. Bacterial food-borne illness outbreaks in northern Taiwan, 1995-2001. J. Infect. Chemother. 2005, 11, 146-151. [CrossRef] [PubMed]

8. Terzi Gulel, G.; Martinez-Urtaza, J. Molecular characterizations of Vibrio parahaemolyticus in seafood from the Black Sea, Turkey. Lett. Appl. Microbiol. 2016, 62, 494-500. [CrossRef] [PubMed]

9. Qu, M.; Deng, Y.; Zhang, X.; Liu, G.; Huang, Y.; Lin, C.; Li, J.; Yan, H.; Li, X.; Jia, L.; et al. Etiology of acute diarrhea due to enteropathogenic bacteria in Beijing, China. J. Infect. 2012, 65, 214-222. [CrossRef] [PubMed]

10. Hiyoshi, H.; Kodama, T.; Iida, T.; Honda, T. Contribution of Vibrio parahaemolyticus virulence factors to cytotoxicity, enterotoxicity, and lethality in mice. Infect. Immun. 2010, 78, 1772-1780. [CrossRef] [PubMed]

11. Kushawaha, A.; Mobarakai, N.; Cooper, M.; Rose, K.; Awasum, M. Necrotising fasciitis with Vibrio vulnificus: A limb threatening dermatologic complication following exposure to marine life. BMJ Case Rep. 2010. [CrossRef] [PubMed]

12. Bisharat, N.; Agmon, V.; Finkelstein, R.; Raz, R.; Ben-Dror, G.; Lerner, L.; Soboh, S.; Colodner, R.; Cameron, D.N.; Wykstra, D.L.; et al. Clinical, epidemiological, and microbiological features of Vibrio vulnificus biogroup 3 causing outbreaks of wound infection and bacteraemia in Israel. Lancet 1999, 354, 1421-1424. [CrossRef]

13. Oliver, J.D. Wound infections caused by Vibrio vulnificus and other marine bacteria. Epidemiol. Infect. 2005, 133, 383-391. [CrossRef] [PubMed]

14. Vickery, M.C.; Nilsson, W.B.; Strom, M.S.; Nordstrom, J.L.; DePaola, A. A real-time PCR assay for the rapid determination of 16S rRNA genotype in Vibrio vulnificus. J. Microbiol. Methods 2007, 68, 376-384. [CrossRef] [PubMed]

15. Ramamurthy, T.; Chowdhury, G.; Pazhani, G.P.; Shinoda, S. Vibrio fluvialis: An emerging human pathogen. Vibrio Ecol. Pathog. Evolut. 2014, 5, 91. [CrossRef] [PubMed]

16. Lagana, P.; Caruso, G.; Minutoli, E.; Zaccone, R.; Delia, S. Susceptibility to antibiotics of Vibrio spp. and Photobacterium damsela ssp. piscicida strains isolated from Italian aquaculture farms. New Microbiol. 2011, 34, 53-63. [PubMed]

17. Igbinosa, E.O.; Okoh, A.I. Vibrio fluvialis: An unusual enteric pathogen of increasing public health concern. Int. J. Environ. Res. Public Health 2010, 7, 3628-3643. [CrossRef] [PubMed] 
18. Adebayo-Tayo, B.C.; Okonko, I.O.; Esen, C.U.; Odu, N.N.; Onoh, C.C.; Igwiloh, N.J.P. Incidence of potentially pathogenic Vibrio spp. in fresh seafood from Itu Creek in Uyo, Akwa Ibom State, Nigeria. World Appl. Sci. J. 2011, 15, 985-991.

19. Waldor, M.K.; Mekalanos, J.J. Lysogenic conversion by a filamentous phage encoding cholera toxin. Science 1996, 272, 1910. [CrossRef] [PubMed]

20. Bina, X.R.; Taylor, D.L.; Vikram, A.; Ante, V.M.; Bina, J.E. Vibrio cholerae ToxR downregulates virulence factor production in response to cyclo (Phe-Pro). mBio 2013, 4, e00366-13. [CrossRef] [PubMed]

21. Terzi, G.; Büyüktanı, Ö.; Yurdusev, N. Detection of the $t$ dh and trh genes in Vibrio parahaemolyticus isolates in fish and mussels from Middle Black Sea Coast of Turkey. Lett. Appl. Microbiol. 2009, 49, 757-763. [CrossRef] [PubMed]

22. Jones, M.K.; Oliver, J.D. Vibrio vulnificus: Disease and pathogenesis. Infect. Immun. 2009, 77, $1723-1733$. [CrossRef] [PubMed]

23. Chakraborty, R.; Sinha, S.; Mukhopadhyay, A.K.; Asakura, M.; Yamasaki, S.; Bhattacharya, S.K.; Nair, G.B.; Ramamurthy, T. Species-specific identification of Vibrio fluvialis by PCR targeted to the conserved transcriptional activation and variable membrane tether regions of the toxR gene. J. Med. Microbiol. 2006, 55, 805-808. [CrossRef] [PubMed]

24. Liang, P.; Cui, X.; Du, X.; Kan, B.; Liang, W. The virulence phenotypes and molecular epidemiological characteristics of Vibrio fluvialis in China. Gut Pathog. 2013, 5, 6. [CrossRef] [PubMed]

25. Igbinosa, E.O.; Obi, L.C.; Okoh, A.I. Occurrence of potentially pathogenic vibrios in final effluents of a wastewater treatment facility in a rural community of the Eastern Cape Province of South Africa. Res. Microbiol. 2009, 160, 531-537. [CrossRef] [PubMed]

26. Igbinosa, E.O.; Obi, C.L.; Okoh, A.I. Seasonal abundance and distribution of Vibrio species in the treated effluent of wastewater treatment facilities in suburban and urban communities of Eastern Cape Province, South Africa. J. Microbiol. 2011, 49, 224-232. [CrossRef] [PubMed]

27. Okoh, A.I.; Sibanda, T.; Nongogo, V.; Adefisoye, M.; Olayemi, O.O.; Nontongana, N. Prevalence and characterisation of non-cholerae Vibrio spp. in final effluents of wastewater treatment facilities in two districts of the Eastern Cape Province of South Africa: Implications for public health. Environ. Sci. Pollut. Res. 2015, 22, 2008-2017. [CrossRef] [PubMed]

28. American Public Health Association (APHA). Standard Methods for Examination of Water and Waste Water, 20th ed.; APHA-AWWA-WEF: Washington, DC, USA, 1998; pp. 9-56.

29. Kwok, A.Y.; Wilson, J.T.; Coulthart, M.; Ng, L.K.; Mutharia, L.; Chow, A.W. Phylogenetic study and identification of human pathogenic Vibrio species based on partial hsp60 gene sequences. Can. J. Microbiol. 2002, 48, 903-910. [CrossRef] [PubMed]

30. Neogi, S.B.; Chowdhury, N.; Asakura, M.; Hinenoya, A.; Haldar, S.; Saidi, S.M.; Kogure, K.; Lara, R.J.; Yamasaki, S. A highly sensitive and specific multiplex PCR assay for simultaneous detection of Vibrio cholerae, Vibrio parahaemolyticus and Vibrio vulnificus. Lett. Appl. Microbiol. 2010, 51, 293-300. [CrossRef] [PubMed]

31. Goel, A.K.; Ponmariappan, S.; Kamboj, D.V.; Singh, L. Single multiplex polymerase chain reaction for environmental surveillance of toxigenic-Pathogenic O1 and non-O1Vibrio cholerae. Folia Microbiol. 2007, 52, 81-85. [CrossRef]

32. Kim, Y.B.; Okuda, J.; Matsumoto, C.; Takahashi, N.; Hashimoto, S.; Nishibuchi, M. Identification of Vibrio parahaemolyticus strains at the species level by PCR targeted to the toxR gene. J. Clin. Microbiol. 1999, 37, 1173-1177. [PubMed]

33. Rosche, T.M.; Yano, Y.; Oliver, J.D. A rapid and simple PCR analysis indicates there are two subgroups of Vibrio vulnificus which correlate with clinical or environmental isolation. Microbiol. Immun. 2005, 49, 381-389. [CrossRef]

34. Zaidenstein, R.; Sadik, C.; Lerner, L.; Valinsky, L.; Kopelowitz, J.; Yishai, R.; Agmon, V.; Parsons, M.; Bopp, C.; Weinberger, M. Clinical characteristics and molecular subtyping of Vibrio vulnificus illnesses, Israel. Emerg. Infect. Dis. 2008, 14, 1875-1882. [CrossRef] [PubMed]

35. Huss, H.H. Control of indigenous pathogenic bacteria in seafood. Food Control 1997, 8, 91-98. [CrossRef]

36. Igbinosa, E.O. Detection and antimicrobial resistance of Vibrio isolates in aquaculture environments: Implications for public health. Microb. Drug Resist. 2016, 22, 238-245. [CrossRef] [PubMed]

37. Nsofor, C.A.; Kemajou, S.T.; Nsofor, C. MIncidence and antibiotic susceptibility pattern of Vibrio species isolated from sea foods sold in Port-Harcourt, Nigeria. Afr. J. Bacteriol. Res. 2014, 6, 13-16.

38. Furniss, A.L.; Lee, J.V.; Donovan, T.J. Group F, a new Vibrio? Lancet 1977, 310, 565-566. [CrossRef] 
39. Kobayashi, K.; Ohnaka, T. Food poisoning due to newly recognized pathogens. Asian Med. J. 1989, 32, 1-12.

40. Thekdi, R.J.; Lakhani, A.G.; Rale, V.B.; Panse, M.V. An outbreak of food poisoning suspected to be caused by Vibrio fluvialis. J. Diarrhoeal Dis. Res. 1990, 8, 163-165. [PubMed]

41. Levine, W.C.; Griffin, P.M. Gulf Coast Vibrio Working Group. Vibrio infections on the Gulf Coast: Results of first year of regional surveillance. J. Infect. Dis. 1993, 167, 479-483. [CrossRef] [PubMed]

42. Lai, C.H.; Hwang, C.K.; Chin, C.; Lin, H.H.; Wong, W.W.; Liu, C.Y. Severe watery diarrhoea and bacteraemia caused by Vibrio fluvialis. J. Infect. 2006, 52, e95-e98. [CrossRef] [PubMed]

43. Miron, D.; Lev, A.; Colodner, R.; Merzel, Y. Vibrio vulnificus necrotizing fasciitis of the calf presenting with compartment syndrome. Pediatr. Infect. Dis. J. 2003, 22, 666-668. [CrossRef] [PubMed]

44. Mead, P.S.; Slutsker, L.; Dietz, V.; McCaig, L.F.; Bresee, J.S.; Shapiro, C.; Griffin, P.M.; Tauxe, R.V. Food-related illness and death in the United States. Emerg. Infect. Dis. 1999, 5, 607. [CrossRef] [PubMed]

45. Morris, J.G.; Acheson, D. Cholera and other types of vibriosis: A story of human pandemics and oysters on the half shell. Clin. Infect. Dis. 2003, 37, 272-280. [CrossRef] [PubMed]

46. Wong, H.C.; Lui, S.H.; Wang, T.K.; Lee, C.L.; Chiou, C.S.; Lui, D.P.; Nishibuchi, M.; Lee, B.K. Characterisation of Vibrio paraheamolyticus O3:K6 from Asia. App. Environ. Microbiol. 2000, 66, 3981-3986. [CrossRef]

47. Zulkifli, Y.; Alitheen, N.B.; Son, R.; Yeap, S.K.; Lesly, M.B.; Raha, A.R. Identification of Vibrio parahaemolyticus isolates by PCR targeted to the ToxR gene and detection of virulence genes. Int. Food Res. J. 2009, 16, $289-296$.

48. Koralage, M.S.G.; Alter, T.; Pichpol, D.; Strauch, E.; Zessin, K.H.; Huehn, S. Prevalence and molecular characteristics of Vibrio spp. isolated from preharvest shrimp of the North Western Province of Sri Lanka. J. Food Prot. 2012, 75, 1846-1850. [CrossRef] [PubMed]

49. Jones, J.L.; Lüdeke, C.H.; Bowers, J.C.; Garrett, N.; Fischer, M.; Parsons, M.B.; Bopp, C.A.; DePaola, A. Biochemical, serological, and virulence characterization of clinical and oyster Vibrio parahaemolyticus isolates. J. Clin. Microbiol. 2012. [CrossRef] [PubMed]

50. Li, Y.; Xie, X.; Shi, X.; Lin, Y.; Qiu, Y.; Mou, J.; Chen, Q.; Lu, Y.; Zhou, L.; Jiang, M.; et al. Vibrio parahaemolyticus, Southern Coastal Region of China, 2007-2012. Emerg. Infect. Dis. 2014, 20, 685-688. [CrossRef] [PubMed]

51. Pazhani, G.P.; Bhowmik, S.K.; Ghosh, S.; Guin, S.; Dutta, S.; Rajendran, K.; Saha, D.R.; Nandy, R.K.; Bhattacharya, M.K.; Mukhopadhyay, A.K.; et al. Trends in the epidemiology of pandemic and non-pandemic strains of Vibrio parahaemolyticus isolated from diarrheal patients in Kolkata, India. PLoS Negl. Trop. Dis. 2014, 8, e2815. [CrossRef] [PubMed]

52. Mahoney, J.C.; Gerding, M.J.; Jones, S.H.; Whistler, C.A. Comparison of the pathogenic potentials of environmental and clinical Vibrio parahaemolyticus strains indicates a role for temperature regulation in virulence. Appl. Environ. Microbiol. 2010, 76, 7459-7465. [CrossRef] [PubMed]

53. Raghunath, P. Roles of thermostable direct hemolysin (TDH) and TDH-related hemolysin (TRH) in Vibrio parahaemolyticus. Front. Microbiol. 2015, 5, 805. [CrossRef] [PubMed]

54. Gulig, P.A.; Bourdage, K.L.; Starks, A.M. Molecular pathogenesis of Vibrio vulnificus. J. Microbiol. 2005, 43 (Suppl. S1), 118-131. [PubMed]

55. Bier, N.; Diescher, S.; Strauch, E. Multiplex PCR for detection of virulence markers of Vibrio vulnificus. Lett. Appl. Microbiol. 2015, 60, 414-420. [CrossRef] [PubMed]

56. Warner, E.; Oliver, J.D. Population structures of two genotypes of Vibrio vulnificus in oysters (Crassostrea virginica) and seawater. Appl. Environ. Microbiol. 2008, 74, 80-85. [CrossRef] [PubMed]

57. Guerrero, A.; Gómez Gil Rodríguez, B.; Wong-Chang, I.; Lizárraga-Partida, M.L. Genetic characterization of Vibrio vulnificus strains isolated from oyster samples in Mexico. Int. J. Environ. Health Res. 2015, 25, 614-627. [CrossRef] [PubMed]

58. Amaro, C.; Biosca, E.G. Vibrio vulnificus biotype 2, pathogenic for eels, is also an opportunistic pathogen for humans. Appl. Environ. Microbiol. 1996, 62, 1454-1457. [PubMed]

59. Sanjuán, E.; Amaro, C. Multiplex PCR assay for detection of Vibrio vulnificus biotype 2 and simultaneous discrimination of serovar E strains. Appl. Environ. Microbiol. 2007, 73, 2029-2032. [CrossRef] [PubMed]

(C) 2017 by the authors. Licensee MDPI, Basel, Switzerland. This article is an open access article distributed under the terms and conditions of the Creative Commons Attribution (CC BY) license (http:/ / creativecommons.org/licenses/by/4.0/). 